УДК 614.252:37.015.3

DOI:

Галина Стечак, кандидат педагогічних наук, стариий викладач кафедри украӥнознавства Львівського національного медичного університету імені Данила Галицького

\title{
ФОРМУВАННЯ ТА РОЗВИТОК ПЕДАГОГІЧНОЇ КОМПЕТЕНТНОСТІ У СТУДЕНТІВ МЕДИЧНИХ ЗАКЛАДІВ ВИЩОЇ ОСВІТИ 3 ВИКОРИСТАННЯМ ІННОВАЦІЙНИХ ТЕХНОЛОГІЙ
}

У статті визначено сутність поняття педагогічної компетентності сімейних лікарів з урахуванням особливостей їхньої професійної діяльності та запропоновано використання інноваційних технологій у контексті педагогічної підготовки медичних працівників. На думку автора, з педагогічною підготовкою сімейних лікарів у медичних закладах вищої освіти пов'язані актуальні проблеми професійної освіти та повсякденної діяльності фахівців цьього профілю. Суспільна значущість роботи сімейних лікарів, складність i багатоаспектність їхніх професійних обов'язків вимагають від них не лише високого рівня професійної підготовки, фундаментальних знань теорії та практики медицини, опанування навичками, тактикою, відповідними методами і прийомами лікарської діяльності, а й передбачають володіння педагогічними знаннями, уміннями і навичками.

Ключові слова: сімейний лікар; медичний заклад вищої освіти; педагогічна компетентність; інновачійні технологіï.

Лim. 16.

Halyna Stechak, Ph.D.(Pedagogy), Senior Lecturer of the Ukrainian Studies Department Danylo Halytskiy National Medical University of Lviv

\section{FORMATION AND DEVELOPMENT OF PEDAGOGICAL COMPETENCE IN STUDENTS OF HIGHER MEDICAL EDUCATION INSTITUTIONS WITH THE USE OF INNOVATIVE TECHNOLOGIES}

The article defines the essence of the concept of pedagogical competence of family doctors taking into account the peculiarities of their professional activity. It also offers the use of innovative technologies within the context of pedagogical training of medical workers. According to the author, the current problems of vocational education and daily activities of the specialists of this field are connected with pedagogical training of family doctors in institutions of higher medical education. The social value of the family doctors' work, the complexity and multidimensionality of their professional responsibilities require not only a high level of professional training, basic knowledge of the theory and practice of medicine, mastering the skills, tactics, appropriate methods and techniques of medical activity, but also provide for the mastery of pedagogical knowledge, abilities and skills. The pedagogical competence of a general practitioner or a family medicine doctor includes personal and activityrelated characteristics, socially and professionally important qualities of a health worker, that express his or her knowledge, abilities, skills and being able to apply them in the treatment and prevention process. These are the components of pedagogical competence of a family doctor: the professionally directed concept "I am a medical educator", which should manifest itself directly in professional activity, communicative interaction, in the system of self-development and self-improvement of a personality; informational and instrumental readiness for activities, that imply possession of professional-medical and psychological-pedagogical knowledge and skills necessary for the quality performance of therapeutic and preventive activities; professional-active consciousness, which is based on the system of values of a person and oriented on its development and awareness of ethical norms of pedagogical activity. The traditional model of the family doctors' training, unfortunately, does not provide for the filling of curricula and programs with pedagogical content. The need for the proper scientific basis for appropriate methodological approaches to the gradual formation and development of pedagogical competence of medical students and effective innovative technologies (interactive, game, problem and context training, information and communication) is obvious. Thus, based on the analysis of the professional functions of family doctors in the context of their social-educational activity, the issue of pedagogical training of students of medical universities is being actualized.

Keywords: a family doctor; family medicine; higher medical school; pedagogical competence; competence.

П остановка проблеми. Розвиток української медичної освіти у XXI ст. спрямований на підвищення якості підготовки і рівня кваліфікації медичних працівників, що потребує нової методології організації освітнього процесу. Згідно 3 нормативними документами Всесвітньої організації охорони здоров'я, завданням медичної 


\section{ФОРМУВАННЯ ТА РОЗВИТОК ПЕДАГОГІЧНОӤ КОМПЕТЕНТНОСТІ У СТУДЕНТІВ МЕДИЧНИХЗАКЛАДІВ ВИЩОЇОСВІТИЗ ВИКОРИСТАННЯМ ІННОВАЦІЙНИХ ТЕХНОЛОГІЙ}

галузі є всебічна турбота про людей та їхнє соціальне середовище. Сімейні лікарі мають розглядати своїх пацієнтів у широкому контексті, турбуватися не лише про діагностику та лікування, а й про запобігання захворювань і травматизму, навчати родини методам догляду і самодогляду, проводити роз'яснювальну роботу та виховувати в пацієнтів свідоме ставлення до збереження здоров’я. Отже, професійна діяльність сімейного лікаря потребує здатності та готовності до виконання низки специфічних функцій психологічного та педагогічного характеру. Ці соціально та професійно важливі якості фахівця нині розглядають крізь призму поняття “професійна компетентність" і в площині компетентнісного підходу до освіти. Тому професійна освіта сімейних лікарів має передбачати формування та розвиток у студентів медичних закладів вищої освіти (ЗВО) педагогічної компетентності.

Літературний огляд. Питанням удосконалення медичної освіти приділяється постійна увага: досліджено та методологічно обгрунтовано специфіку професійної діяльності медиків; визначено кваліфікаційні вимоги до фахівців медичного профілю; розроблено структуру медичної освіти та напрями іiі здійснення. Для розвитку, адекватного завданням часу, в системи охорони здоров'я розроблена й упроваджена безперервна освіта медиків [10].

Окремі дослідники наголошують на значенні впровадження педагогічної підготовки у процес навчання майбутніх медиків, яка сприятиме усвідомленню майбутніми медичними працівниками необхідності профілактики та ранньої діагностики різних захворювань, а не лише їх лікування у хворих [6]. Проте, не зважаючи на впровадження психологічних і педагогічних дисциплін, загалом педагогічній підготовці майбутніх лікарів у освітньому процесі українських медичних 3ВО нині, як правило, належна увага не приділяється. Ми погоджуємося 3 твердженням, що медична освіта передбачає підготовку фахівців до виконання функцій організатора допомоги пацієнту, наставника, співрозмовника $[13,41]$. У деяких дослідженнях [1; 12] справедливо відзначається, що для організації догляду за хворим медичний працівник зобов'язаний знати, що його діяльність має спрямовуватися на вирішення не лише медичних проблем, а й психологічних і соціальних. Однак, формування педагогічної компетентності вивчалося лише щодо медичного працівника із середньою професійною освітою, а завдання цілісного дослідження процесу педагогічної підготовки лікаря практично не ставилися. У психолого-педагогічній літературі не розкриті зміст і структура поняття "педагогічна компетентність лікаря”, не розроблена система форм і методів педагогічної підготовки, а також не обгрунтовано комплекс технологій, за яких процес формування педагогічної компетентності в майбутнього лікаря, зокрема сімейного, буде ефективним. У науковій літературі нині теж активно досліджуються різні проблеми сімейної медицини [16]. Проте питання педагогічної підготовки в них практично не розглядаються.

Мета та завдання дослідження. Мета статті полягає в науковому обгрунтуванні методичних підходів та інноваційних технологій поетапного формування та розвитку педагогічної компетентності майбутніх сімейних лікарів у медичному університеті.

Для досягнення мети були поставлені такі завдання:

1. Визначити сутність і структуру педагогічної компетентності сімейних лікарів.

2. Розробити методичні рекомендації щодо поетапного формування та розвитку педагогічної компетентності студентів-медиків.

3. Запропонувати інноваційні технологій педагогічної підготовки майбутніх сімейних лікарів.

Виклад основного матеріалу. Педагогічна компетентність сімейних лікарів та шляхи iii формування в медичних університетах. Відповідно до Енциклопедії освіти, компетентність $є$ результатом освіти, вираженим у системі знань, умінь, навичок, особистісних якостей, практичного досвіду, яка передбачає готовність особистості до мобілізації внутрішніх і зовнішніх ресурсів [2, 409]. Компетентність свідчить про освітній рівень і досвідченість людини, що включає також особистісне ставлення до діяльності, мотиваційноціннісні аспекти та інші якості, що дозволяють бути успішним. Під професійною компетентністю розуміють інтегративне особистісно-діяльнісне новоутворення, що збалансовано поєднує необхідні знання, уміння та навички, професійно важливі якості, ціннісні орієнтації та певний досвід діяльності, котрі дозволяють самостійно та якісно виконувати основні функціональні обов'язки. У контексті наших наукових пошуків ми розуміємо компетенцію, як визначені нормативи професійної підготовки, а компетентність - як характеристику фахівця, котра поєднує не лише знаннєвий і технологічний, а й мотиваційний, етичний, соціальний і поведінковий аспекти.

Основна суть педагогічної компетентності полягає в єдності психолого-педагогічних знань, 


\section{ФОРМУВАННЯ ТА РОЗВИТОКПЕДАГОГІЧНОЇ КОМПЕТЕНТНОСТІ У СТУДЕНТІВ МЕДИЧНИХЗАКЛАДІВ ВИЩОЇОСВІТИ З ВИКОРИСТАННЯМ ІННОВАЦІЙНИХ ТЕХНОЛОГІЙ}

умінь, досвіду, властивостей і якостей педагога, що дозволяють ефективно виконувати навчальновиховну діяльність, цілеспрямовано організовувати педагогічну взаємодію, а також передбачають саморозвиток, самовиховання, вдосконалення особистості та майстерності викладача. Це цілісна професійно-особистісна характеристика, яка визначає готовність і здатність виконувати педагогічні функції відповідно до прийнятих норм, стандартів, вимог [4, 7 - 8]. Педагогічна компетентність передбачає, що фахівець здатний ефективно використовувати весь обсяг людських знань у справі виховання та навчання, тобто в достатній мірі володіє формами, методами i способами освітньої діяльності, здатен системно сприймати педагогічну реальність і при цьому діяти оптимально. Це забезпечує можливість цілісного, структурованого бачення логіки освітніх процесів, розуміння закономірностей, принципів і тенденцій розвитку педагогічної системи, дозволяє проектувати і конструювати раціональну освітню діяльність.

На основі цих тверджень, педагогічна компетентність медичного прачівника комплексна, багатофакторна характеристика: сукупність знань, умінь, навичок, а також властивостей особистості, що сприяють успішному психологічному і терапевтичному впливу на пацієнтів і дозволяють найбільш ефективно організувати лікувально-профілактичний процес, регулювати різні аспекти психологопедагогічної діяльності у процесі вирішення професійних завдань [2, 10]. Психологопедагогічна компетентність, на наш погляд, є основою для реалізації таких функцій лікарської діяльності: 1) лікувально-профілактичних; 2) психолого-просвітницьких; 3) соціальноорганізаторських.

Педагогічна компетентність сімейних лікарів, як інтегрована характеристика особистості, охоплює систему їхніх соціально та професійно важливих якостей, якій властиві складні, різнорівневі внутрішні зв'язки. Зарубіжний досвід професійної підготовки майбутніх сімейних лікарів і розвитку сімейної медицини, зокрема у США [14] та в Свропейських країнах $[15,16]$ свідчить, що педагогічна компетентність є вагомою складовою лікувально-профілактичного процесу та неодмінно має розглядатися в контексті професійної підготовки. Тому вважаємо, що професійна підготовка майбутніх сімейних лікарів обов'язково має враховувати компоненти їхньої педагогічної компетентності (мотиваційноціннісний, знаннєвий, професійно-комунікативний, організаційно-технологічний і рефлексивний). Для забезпечення дієвого педагогічного впливу викладачам медичних 3ВО потрібно розробляти і застосовувати стратегії професійно-теоретичної та професійно-практичної діяльності; приймати і реалізовувати управлінські рішення; здійснювати аналіз інформаційних потоків; організовувати й управляти педагогічними процесами; керувати груповою динамікою та упорядковувати міжособистісні стосунки студентів $[9,40]$.

Формування педагогічної компетентності майбутніх сімейних лікарів розуміємо як спеціально організований цілеспрямований процес, який передбачає декілька етапів: опанування курсу педагогіки відповідно до навчального плану; засвоєння елементів педагогічних знань і вмінь у процесі вивчення окремих загальнонаукових (біомедичними) і професійно орієнтованих (медичних) дисциплін; вивчення педагогічно орієнтованого спецкурсу на випускному курсі; набуття власного досвіду практичної професійнопедагогічної діяльності майбутніх сімейних лікарів під час первинної професійної спеціалізації (навчання в інтернатурі). Проектування його форм, методів і засобів надає навчанню ознак технологічності, робить його керованим, наперед визначаючи якісні показники [5, 42]. Принципи концептуальності, поетапності та безперервності педагогічної підготовки сімейних лікарів передбачають цілеспрямоване, невпинне та поетапне формування професійно-педагогічних якостей студентів медичних 3ВО.

Проектування форм, методів і засобів розвитку педагогічної компетентності сімейних лікарів відображає характер педагогічного впливу на їі формування у процесі професійної підготовки. Для керованого формування та розвитку компонентів педагогічної компетентності важливо організувати педагогічну підготовку в медичному університеті таким чином, щоб забезпечити: використання різних форм організації освітнього процесу 3 метою зацікавлення студентів педагогічними аспектами майбутньої професійної діяльності, стимулювання мотивації щодо вдосконалення професійно-педагогічних якостей; поєднання традиційних та інноваційних методів і сучасних педагогічних технологій із метою формування навичок педагогічної діяльності; надання студентам широких можливостей для творчого застосування педагогічних знань, умінь і навичок у реальних і змодельованих професійнопедагогічних ситуаціях; організацію контролю й оцінювання рівня сформованості в майбутніх сімейних лікарів кожного 3 компонентів педагогічної компетентності. Для цього пропонуємо включити розширений комплекс 


\section{ФОРМУВАННЯ ТА РОЗВИТОК ПЕДАГОГІЧНОЇ КОМПЕТЕНТНОСТІ У СТУДЕНТІВ МЕДИЧНИХЗАКЛАДІВ ВИЩОЇ ОСВІТИЗ ВИКОРИСТАННЯМ ІННОВАЦІЙНИХ ТЕХНОЛОГІЙ}

педагогічно спрямованих тестових питань в ліцензійні інтегровані іспити “Крок”, які складають студенти та інтерни з основних медико-біологічних і професійно орієнтованих дисциплін [8, 49 - 50]. Їх зміст затверджується щорічно Міністерством охорони здоров’я України і повинен відповідати освітньо-професійним програмам, які узгоджуються Міністерством освіти [11]. Побудова освітнього процесу на таких засадах сприяє ефективному опануванню студентами педагогічною діяльністю та дає їм змогу самореалізуватися вже під час навчання в медичному університеті.

Загалом проектування та використання форм, методів і засобів поетапного формування та розвитку в освітньому процесі педагогічної компетентності у студентів спрямоване на підвищення ефективності педагогічної підготовки майбутніх сімейних лікарів і передбачає:

- зорієнтованість форм, методів і засобів розвитку педагогічної компетентності студентів на формування їхньої готовності продуктивно виконувати професійно-педагогічну діяльність;

- організацію педагогічної взаємодії, доцільний відбір форм, методів і технологій навчання для збагачення та систематизації цінностей, норм і знань, спрямованих на формування педагогічної компетентності студентів;

- забезпечення майбутніх сімейних лікарів педагогічними знаннями і практичними вміннями і навичками виконання професійно-педагогічної діяльності на основі їх поетапної інтеріоризації у процесі навчання;

- задоволення потреб майбутніх сімейних лікарів у невпинному підвищенні педагогічної компетентності, розширенні світогляду, вивчення вітчизняного і зарубіжного досвіду професійнопедагогічної підготовки відповідно до досягнень сучасної психолого-педагогічної науки і новітніх технологій навчання.

Педагогічна компетентність сімейних лікарів грунтується на вміннях планувати освітній процес під час лікування пацієнтів, самостійно підходити до вирішення професійно-педагогічних завдань на основі аналізу ситуації, чітко виконувати заплановане, здійснюючи необхідну корекцію відповідно до одержаних результатів. 3 метою розвитку в студентів цих умінь процес педагогічної підготовки у ЗВО має відповідати завданням і реаліям системи охорони здоров'я. Насправді ж вивчення педагогічних дисциплін та одержання практичних умінь і навичок не завжди дає студентам можливість уявити процес професійно-педагогічної діяльності в конкретних ситуаціях, оскільки його неможливо достеменно відтворити під час навчання. Стосовно сімейних лікарів цей аспект ускладнюється тим, що досить важко об'єктивно змоделювати педагогічну взаємодію з пацієнтом і створити універсальний шаблон їі перебігу в реальному лікувальнопрофілактичному процесі. Подоланню цих труднощів сприятиме максимальне наближення технологій педагогічної підготовки до медичної практики, внаслідок чого підвищиться готовність студентів психологічно адаптуватися до професійної діяльності.

Відповідно до принципів емоційної активності, соціальної взаємодії, комплексності, інноваційності формування педагогічної компетентності як вагомого чинника успішності лікувальнопрофілактичного процесу має здійснюватися за допомогою розроблення й упровадження інноваційних педагогічних технологій. На особливу увагу в процесі педагогічної підготовки майбутніх сімейних лікарів заслуговують технології, здатні суттєво покращити основні показники сформованості їхньої педагогічної компетентності. Ї̈̈ формування, безперечно, залежить від зацікавленості й активності студентів, їхнього бажання досягти високого рівня професійної кваліфікації. У зв'язку з цим у педагогічній підготовці сімейних лікарів доцільно використовувати технології навчання, продуктивність яких “спричинюється їхньою проблемізацією, структурним наповненням прийомами логічного мислення (аналіз, синтез, порівняння, підсумування, узагальнення, систематизація, індукція, дедукція, аналогія) і посилюється внутрішнім коефіцієнтом активності” [7, 96]. Вони мають відрізнятися інтенсивною подачею матеріалу, пізнавальною та емоційною активністю студентів, постійним самоконтролем, діалогічністю, проблемністю тощо. Ефективними засобами педагогічної підготовки майбутніх сімейних лікарів $є$ застосування інноваційних джерел навчальної інформації (Інтернет, електронні освітні ресурси, бази даних тощо).

Упровадження у процес педагогічної підготовки майбутніх лікарів сімейної медицини інноваційних технологій має відбуватися системно та комплексно як на теоретичних, так і на практичних заняттях. Їх доцільно спрямовувати на: проектування індивідуального особистісного розвитку кожного студента, стимулювання навчальної діяльності за допомогою розв'язання практичних ситуацій, постановки і творчого вирішення проблем, обмін досвідом; формування компонентів педагогічної компетентності 3 урахуванням індивідуальних особливостей 


\section{ФОРМУВАННЯ ТА РОЗВИТОК ПЕДАГОГІЧНОЇ КОМПЕТЕНТНОСТІ У СТУДЕНТІВ МЕДИЧНИХЗАКЛАДІВ ВИЩОЇ ОСВІТИЗ ВИКОРИСТАННЯМ ІННОВАЦІЙНИХ ТЕХНОЛОГІЙ}

студентів та їхніх схильностей; забезпечення взаємозв'язку освітніх цілей із безпосередніми професійно-педагогічними завданнями сімейного лікаря тощо [3].

Одним із найважливіших чинників, що забезпечують мотивацію студентів до формування педагогічної компетентності $\epsilon$ емоційне переживання сутності змісту педагогічної підготовки й усвідомлення її важливості для успішної професійної діяльності. Завдяки застосуванню інноваційних технологій навчання стає особистісно значущим, оскільки студенти залучаються до самостійного вирішення складних проблем, які можуть виникнути в реальній професійно-педагогічній діяльності, зокрема у відносинах лікаря з пацієнтами, його родичами тощо. Це актуалізує предметний і соціальний контексти педагогічної діяльності сімейних лікарів та відображає ii зміст у їхній професійній підготовці, дає змогу формувати i розвивати педагогічну техніку як основу педагогічної майстерності.

Отже, упровадження інноваційних технологій теоретичної та практичної підготовки сімейних лікарів студентів передбачає:

- цілеспрямоване використання на теоретичних і практичних заняттях з педагогічної підготовки досягнень психології та педагогіки, інноваційних технологій навчання, які підвищать ефективність професійно-педагогічної діяльності;

- застосування контекстного навчання, що забезпечує цілісне уявлення студентів про предметний і соціальний зміст професійнопедагогічної діяльності;

- зорієнтованість технологій педагогічної підготовки сімейних лікарів на вироблення системи внутрішніх засобів регуляції професійнопедагогічних дій;

- постійний моніторинг сформованості компонентів педагогічної компетентності студентів і коригування педагогічної підготовки за його результатами.

Результати дослідження. Позитивні результати апробації в медичних університетах запропонованих науково-методичних положень свідчить, що організована 3 використанням інноваційних технологій педагогічна підготовка забезпечує мотивацію студентів до педагогічної складової професійної діяльності сімейного лікаря, інтеграцію педагогічних, психологічних, медичних знань, умінь і навичок, що відповідає потребам лікарської практики, а застосування контекстного навчання формує цілісне уявлення студентів про предметний і соціальний зміст подальшої професійної діяльності. Це дає змогу реалізовувати навчання 3 урахуванням перспективних вимог галузі охорони здоров'я до лікарів загальної практики і підвищити якість їхньої підготовки, а також конкурентоздатність на ринку медичних послуг.

Завдяки формуванню мотиваційно-ціннісного ставлення студентів до педагогічної складової професійної діяльності, інтеграції педагогічних, психологічних, медичних знань, умінь і навичок, що відповідає потребам лікарської практики, використанню форм і методів навчання, що забезпечують інтенсифікацію цього процесу, застосуванню ефективних засобів педагогічної підготовки, сучасних джерел навчальної інформації, а також інноваційних технологій в майбутніх сімейних лікарів формуються всі компоненти педагогічної компетентності. Уважаємо, що належна педагогічна підготовка майбутніх сімейних лікарів сприяє досягненню такого рівня якості медичної освіти, що дасть їм змогу швидко включитися у професійну діяльність, бути готовими правильно діяти у складних професійних ситуаціях, виявляти належну компетентність, відповідальність і розвивати власну професійну позицію сімейного лікаря.

До подальших напрямів наукового пошуку відносимо: підвищення педагогічної майстерності науково-педагогічних працівників медичних 3ВО; створення та застосування електронних освітніх ресурсів у підготовці лікарів сімейної медицини; розроблення й удосконалення науковометодичного забезпечення підготовки сімейних лікарів.

Висновки. 1. Педагогічну компетентність сімейного лікаря визначаємо як інтегровану характеристику особистості, яка охоплює комплекс актуалізованих психолого-педагогічних і дотичних спеціально-медичних знань, умінь і навичок, соціально та професійно важливі якості, спрямовані на системне сприйняття медичної діяльності та їі освітніх завдань, усвідомлене опанування формами, методами і технологіями навчально-виховної роботи й організації педагогічної взаємодії з пацієнтами та їхнім оточенням, безперервний розвиток педагогічних здібностей і вдосконалення педагогічної техніки, здатність і готовність застосовувати їх для позитивного психологічного і терапевтичного впливу на пацієнтів.

2. Розроблені й апробовані методичні рекомендації щодо вдосконалення підготовки майбутніх сімейних лікарів передбачають поетапне формування та розвиток педагогічної компетентності студентів: опанування основ 


\section{ФОРМУВАННЯ ТА РОЗВИТОК ПЕДАГОГІЧНОӤ КОМПЕТЕНТНОСТІ У СТУДЕНТІВ МЕДИЧНИХЗАКЛАДІВ ВИЩОЇ ОСВІТИЗ ВИКОРИСТАННЯМ ІННОВАЦІЙНИХ ТЕХНОЛОГИЙ}

педагогіки за модернізованою навчальною програмою; налагодження та реалізацію міждисциплінарних зв'язків педагогіки із загальнонауковими і медичними дисциплінами; цілеспрямоване формування педагогічної компетентності під час вивчення спецкурсу "Педагогічна діяльність лікаря загальної практики"; набуття практичного досвіду професійно-педагогічної діяльності під час первинної професійної спеціалізації.

3. Удосконалення педагогічної підготовки майбутніх сімейних лікарів у медичному університеті потребує комплексного впровадження та реалізації інноваційних технологій (інтерактивних, ігрових, проблемного та контекстного навчання, інформаційно-комунікаційних), спрямованих на засвоєння педагогічних знань і вироблення відповідних умінь, підвищення мотивації самовдосконалення у професійно-педагогічній діяльності та виховання професійно-педагогічних цінностей, розвиток особистісних якостей, необхідних для виконання освітньої діяльності.

\section{ЛІТЕРАТУРА}

1. Балякова И. С. Формирование педагогической компетентности будущего специалиста со средним медицинским образованием : дисс. ... канд. пед. наук : 13.00.08. Саратов, 2006. 202 с.

2. Бібік Н. М. Компетенції. Енциклопедія освіти. АПН України ; голов. ред. В. Г. Кремень. Київ, 2008. С. 409.

3. Исаев В. А., Ворошилов В. И. Образование взрослых: компетентностный подход : учебнометод. пособие / Исаев В. А.,; Рос. акад. Образования, Ин-т образования взрослых. СПб : ИОВ РАО, 2005. $91 \mathrm{c}$.

4. Колісник-Гуменюк Ю. І. Формування професійно-етичної культури майбутніх фахівців у процесі гуманітарної підготовки в медичних коледжах: монографія. Львів, 2013. 296 с.

5. Литвин А. В. Інформатизація професійнотехнічних навчальних закладів будівельного профілю : монографія. Львів, 2011. 498 с.

6. Самборская Е. П. Роль средних медицинских работников в охране репродуктивного здоровья населения. Главная медицинская сестра. 2001. № 4. С. 16-18.

7. Сікорський П. І. До проблеми класифікації методів навчання. Вісник Львів. ун-ту. Серія педагогічна. 2003. Вип. 17. С. 89-98.

8. Стечак Г. М. Основи формування педагогічної компетентності майбутнього лікаря сімейної медицини : навч.-метод. посібник для виклад. медичних ВНЗ. Львів, 2016. 62 с.

9. Стечак Г. М. Структура педагогічної компетентності сімейного лікаря. Професійна освіта : проблеми і перспективи. Київ, 2016. Вип. 10. С. 38-42.

10. Стратегія розвитку медичної освіти в Україні визначена. Освітній портал. URL: http:/ /www.osvita.org.ua/bologna/articles/01.html.

11. Про медичні ліцензійні іспити. Київ, 2016. URL: http://testcentr.org.ua/index.php/menu-mle/ menu-goal.html.

12. Терегулова Э. Н., Назифуллин В. Л. О методических подходах повышения качества сестринской помощи : тез. доклада. Уфа : Башкирский гос. мед. ун-т, 2005. 5 с.

13. Цуцунава М. Р. Медсестринское исследование : навстречу сестринской практике. Главная медиичинкая сестра. 2001. № 1. С. 39-46.

14. Chen P. G., Nunez-Smith M., Bernheim S. M., Berg D., Gozu A., Curry L. A. Professional experiences of international medical graduates practicing primary care in the United States. Journal of General Internal Medicine. 2010. No. 25(9). pp. 947-953.

15. Clarke, O., Monica Lindh, E. B., Mario R. Sammut, Roger Price, Alma Eir Svavarsdottir, Brendan O'Shea Training, status and migration of General Practitioners - Family Physicians within Europe. The Journal of the Malta College of Family Doctors. 2013. No. 2. P. 24-30.

16. Sammut, M. R., Lindh, M., Rindlisbacher, B. Funding of vocational training programmes for general practice/family medicine in Europe. On behalf of EURACT - the European Academy of Teachers in General Practice. European Journal of General Practice. 2008. No. 14. P. 83-88.

\section{REFERENCES}

1. Balyakova, I. S. (2006). Formirovanie pedagogicheskoy kompetentnosti budushchego spetsialista so srednim meditsinskim obrazovaniem [The formation of pedagogical competence of a future specialist with secondary medical education]. Candidate's thesis. Saratov, 202 p. [in Russian].

2. Bibik, N. M. (2008). Kompetentsii [Competences]. The encyclopedia of education. National Academy of Pedagogical Sciences of Ukraine; editor in chief V. H. Kremen. Kyiv, p. 409. [in Ukrainian].

3. Isaev, V. A. \& Voroshilov, V. I. (2005). Obrazovanie vzroslykh: kompetentnostnyy podkhod: uchebno-metod. posobie [Adult education: skills approach: a teaching guide]. Russian Academy of Education, Adult Education Institute. SanktPeterburg, 91 p. [in Russian].

4. Kolisnyk-Humeniuk, Yu. I. (2013). Formuvannia profesiino-etychnoi kultury maibutnikh fakhivtsiv 
u protsesi humanitarnoi pidhotovky $v$ medychnykh koledzhakh: monohrafiia [The formation of professional and ethical culture of future specialists in the process of humanitarian training in medical colleges: a monograph]. Lviv, 296 p. [in Ukrainian].

5. Lytvyn, A. V. (2011). Informatyzatsiia profesiino-tekhnichnykh navchalnykh zakladiv budivelnoho profiliu : monohrafiia [The informatization of vocational-technical constructional educational establishments]. Lviv, 498 p. [in Ukrainian].

6. Samborskaya, Ye. P. (2003). Rol srednikh meditsinskikh rabotnikov v okhrane reproduktivnogo zdorovya naseleniya [The role of intermediate-level medical workers in the protection of the reproductive health of population]. The head nurse. No. 4. pp. 1618. [in Russian].

7. Sikorskyi, P. I. (2003). Do problemy klasyfikatsii metodiv navchannia [To the problem of classification of teaching methods]. Journal of Lviv University. Series: pedagogical. Vol. 17. pp. 89-98. [in Ukrainian].

8. Stechak, H. M. (2016). Osnovy formuvannia pedahohichnoi kompetentnosti maibutnoho likaria simeinoi medytsyny : navch.-metod. posibnyk dlia vyklad. medychnykh VNZ [The foundations for pedagogical competence of a future family medicine doctor: a teaching guide for the university professors]. Lviv, 62 p. [in Ukrainian].

9. Stechak, H. M. (2016). Struktura pedahohichnoi kompetentnosti simeinoho likaria Profesiina osvita : problemy i perspektyvy [The structure of pedagogical competence of a family doctor]. Professional education: problems and prospects. Kyiv: Institute of Vocational and Technical Education National Academy of Pedagogical Sciences of Ukraine, vol. 10, p. 38-42. [in Ukrainian].

10. Stratehiia rozvytku medychnoi osvity $v$
Ukraini vyznachena [The strategy of the development of medical education in Ukraine is defined]. An electronic resource, educational portal. Available at://www.osvita.org.ua/bologna/articles/ 01.html. [in Ukrainian].

11. Pro medychni litsenziini ispyty (2016). [About medical licensing examinations]. Kyiv. Available at: http://testcentr.org.ua/index.php/menu-mle/menugoal.html. [in Ukrainian].

12. Teregulova, E. N. \& Nazifullin, V. L. (2005). $O$ metodicheskikh podkhodakh povysheniya kachestva sestrinskoy pomoshchi : tez. doklada [About methodological approaches on how to improve the quality of the nursing care]. Ufa : Bashkir State Medical University, 5 p. [in Russian].

13. Tsutsunava, M. R. (2001). Medsestrinskoe issledovanie : navstrechu sestrinskoy praktike [Medical research: towards the nursing training]. The head nurse. No. 1., pp. 39-46.

14. Chen, P. G., Nunez-Smith, M., Bernheim, S. M., Berg, D., Gozu, A., Curry, L. A.(2010). Professional experiences of international medical graduates practicing primary care in the United States. Journal of General Internal Medicine. No. 25(9). pp. $947-$ 953. [in English].

15. Clarke, O., Monica Lindh, E. B., Mario R. Sammut, Roger Price, Alma Eir Svavarsdottir, Brendan O'Shea (2013). Training, status and migration of General Practitioners - Family Physicians within Europe. The Journal of the Malta College of Family Doctors. No. 2. pp. 24-30. [in English].

16. Sammut, M. R., Lindh, M. and Rindlisbacher, B. (2008). Vocational training programs funding for general practice/family medicine in Europe. On behalf of EURACT - the European Academy of Teachers in General Practice. European Journal of General Practice. No. 14.pp. 83-88. [in English].

Стаття надійшла до редакції 04.10.2019

\title{
G58080
}

\author{
"Мета життя - самовираження. Лроявити у всій повноті свою сутність - ось для \\ чого ми живемо”.

"Едине, що може направити нас до благородних думок $і$ вчинқів, - це приклад великих і морально чистих особистостей”.

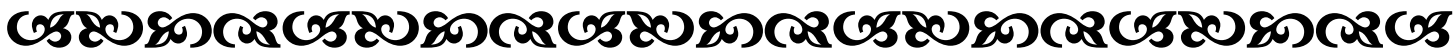

